\title{
Biology of the relict fungus-farming ant Apterostigma megacephala Lattke, including descriptions of the male, gyne, and larva
}

\author{
J. Sosa-Calvo ${ }^{1,2,6}$ • A. Ješovnik ${ }^{2,3}$ - C. T. Lopes ${ }^{4}$ - A. Rodrigues ${ }^{5}$ C C. Rabeling ${ }^{1,6}$ \\ M. Bacci Jr. ${ }^{5}$ H. L. Vasconcelos ${ }^{4}$ T. R. Schultz ${ }^{2}$
}

Received: 19 October 2016 / Revised: 12 January 2017 / Accepted: 6 February 2017 / Published online: 1 March 2017

(C) International Union for the Study of Social Insects (IUSSI) (outside the USA) 2017

\begin{abstract}
Fungus-farming "attine" ant agriculture consists of five distinct agricultural systems characterized by a remarkable symbiont fidelity in which five phylogenetic groups of ants faithfully cultivate five phylogenetic groups of fungi. Across-system garden switching experiments result in colony decline and death, indicating that attine ant-fungus symbiont fidelity is enforced by poorly understood biological constraints. The most dramatic violation of this pattern of symbiont fidelity occurs in the relict species Apterostigma megacephala, the only lower-attine ant known to cultivate a higher-attine fungus. Apterostigma megacephala is the sole surviving representative of an ancient lineage that diverged from all other Apterostigma fungus-farming ants $\sim 39$ million years ago, yet it cultivates Leucoagaricus gongylophorus, a highly domesticated fungal species that originated in the gardens of the recently evolved leaf-cutting ants 8-11 million years ago.
\end{abstract}

T. R. Schultz

schultzt@si.edu

1 Department of Biology, University of Rochester, Rochester, NY 14627, USA

2 Department of Entomology, National Museum of Natural History, Smithsonian Institution, Washington, DC 20013, USA

3 Maryland Center for Systematic Entomology, Department of Entomology, University of Maryland, College Park, MD 20782, USA

4 Instituto de Biologia, Universidade Federal de Uberlândia, Uberlândia, Minas Gerais, Brazil

5 Centro de Estudos de Insetos Sociais, Universidade Estadual Paulista UNESP, Rio Claro, São Paulo, Brazil

6 Present Address: Center for Social Insect Research, School of Life Sciences, Arizona State University, Tempe, AZ 85287, USA
Understanding the biology of A. megacephala, therefore, may provide important clues about the biological mechanisms that constrain the otherwise seemingly obligate antfungus associations that characterize attine ant agriculture. Here, based on field work in the Floresta Nacional de Carajás in the state of Pará in Brazil, we report the previously unknown biology of A. megacephala, including nest architecture, colony demography, foraging behavior, and the morphologies of the previously undescribed gyne, male, and larva.

Keywords Attini $\cdot$ Coevolution $\cdot$ Leucoagaricus gongylophorus $\cdot$ Nest architecture $\cdot$ Symbiosis

\section{Introduction}

Fungus-farming ants (subfamily Myrmicinae, tribe Attini, subtribe Attina; henceforth "attine" ants) are a monophyletic group of exclusively New World ants descended from a common ancestor that transitioned from hunting-gathering to agriculture 55-65 million years ago (Ješovnik et al. 2016; Mueller et al. 2001; Nygaard et al. 2016; Rabeling et al. 2011; Schultz and Brady 2008; Ward et al. 2015; Wilson 1971). Since that origin, attine ant agriculture has diversified into five known agricultural systems characterized by nearly monolithic patterns of symbiont fidelity between broad phylogenetic groups of attine ants, fungal cultivars (Basidiomycota: Agaricales: Agaricaceae [Leucoagaricus and Leucocoprinus] and Pterulaceae), and Escovopsis fungal parasites (Ascomycota: Pezizomycotina: asexual Hypocreales). These five agricultural systems include: (i) lower agriculture, the ancestral system, in which a diverse, paraphyletic group of ants cultivates a diverse group of agaricaceous fungi, which, so far as is 
known, are facultative symbionts, capable of living freely apart from the ants; (ii) yeast agriculture, a derived form of lower agriculture in which ants in a derived clade in the Cyphomyrmex rimosus group cultivate a derived clade of agaricaceous fungi that are also capable of living freely apart from the ants; (iii) coral fungus agriculture, in which ants in a derived clade in the Apterostigma pilosum group cultivate a clade of fungi in the Pterulaceae, and in which the facultative/obligate status of the fungal partner remains unknown; (iv) generalized higher agriculture, in which two genera of "higher" attine ants cultivate a derived clade of agaricaceous fungi that are specialized, obligate symbionts, incapable of life without the ants; and (v) leaf-cutter agriculture, a derived form of higher agriculture, in which most ant species in the ecologically dominant genera Acromyrmex and Atta cultivate a single, highly derived higher-attine fungal species, Leucoagaricus gongylophorus (Aylward et al. 2013; De Fine Licht et al. 2013; Kooij et al. 2015; Nygaard et al. 2016). In contrast to most of their fungal cultivars, all attine ants are obligate symbionts, incapable of surviving without their fungus gardens. Seal et al. (2012) and Seal and Mueller (2014) showed that, when the generalized higher-attine ant species Trachymyrmex septentrionalis is forced to cultivate the leaf-cutter fungus L. gongylophorus, colonies suffer no ill effects in the short term (i.e., 6 weeks), but over longer periods of time colonies decline and die, indicating that cultivar switching across agricultural systems is associated with significant fitness costs.

Although attine ant and fungal cultivar species are remarkably faithful at the level of the five agricultural systems, within each of the agricultural systems, associations between species are apparently uncorrelated with phylogeny, i.e., within a given agricultural system, an ant species may be associated with multiple distantly related fungal cultivar species and vice versa. Based on this lack of congruence across symbiont phylogenies within agricultural systems, the prevailing paradigm for attine symbiotic evolution is one of diffuse coevolution (Mikheyev et al. 2010; Mikheyev et al. 2007; Mikheyev et al. 2008; Mueller et al. 1998). Contrary to this paradigm, however, an intensive study of ant-fungus associations in the Cyphomyrmex wheeleri clade found that ant-fungus species pairs have persisted for 5-10 million years and that rare switches to new cultivars are correlated with and may even have caused ant speciation events (Mehdiabadi et al. 2012), suggesting that diffuse coevolution may apply to some but not all attine agricultural symbioses.

Prior to 2008, Apterostigma megacephala was known from only four specimens collected in 1988, 1989, 1990, and 1992 on the western peripheries of the Amazon basin in southern Peru and eastern Andean Colombia (Lattke 1999; Schultz et al. 2015). Initial morphological studies suggested that A. megacephala was a relict species, retaining a combination of traits more primitive than those found in Apterostigma species fossilized in Dominican amber (Lattke 1999; Schultz 2007). Based on its hypothesized phylogenetic position, A. megacephala was fully expected to cultivate a lower-attine fungus (Schultz 2007). In 2008, da Silva and Brandão discovered a single specimen in a litter sample taken at the opposite end of the Amazon basin in the Floresta Nacional de Carajás (FLONACarajás) in Pará, Brazil, $800 \mathrm{~km}$ south of Belém. Based on this information, two of us (JS-C and CTL) discovered a population of $A$. megacephala in Carajás in 2009, leading to subsequent field investigations in 2010, 2011, and 2014.

Based on phylogenetic analyses of molecular data from ants and fungi obtained in those field investigations, Schultz et al. (2015) reported that A. megacephala is the very distant sister taxon of the remainder of the genus, the sole surviving representative of an ancient lineage that diverged $\sim 39$ million years ago from the ancestor of all other known extant and extinct Apterostigma species. It is, in fact, the oldest known single-species (i.e., relict) fungus-farming ant lineage. Surprisingly, based on molecular data from its fungal cultivar, A. megacephala is the only lower-attine ant known to cultivate a higher-attine fungus. Even more surprisingly, A. megacephala cultivates the most highly derived and recently evolved higher-attine fungal cultivar, Leucoagaricus gongylophorus, the species cultivated by most leaf-cutter ants (Schultz et al. 2015). The cultivation of L. gongylophorus by A. megacephala in eastern Amazonian Brazil can only be due to a horizontal transfer event because $L$. gongylophorus is estimated to have originated 8-10 million years ago (Nygaard et al. 2016). The ability of A. megacephala to cultivate L. gongylophorus is likely to be important for understanding the currently unknown biological constraints enforcing symbiont fidelity at the level of the five attine agricultural systems, in particular the constraints preventing lower-attine ants from cultivating higher-attine fungi.

Here, based on data and specimens gathered during the previously mentioned 2010, 2011, and 2014 field studies, we describe the previously unknown reproductive forms (i.e., males and gynes), larva, nest architecture, and other aspects of the biology of this remarkable fungus-farming ant species.

\section{Materials and methods}

\section{Study area, field observations, and nest excavations}

Field work was conducted at Floresta Nacional de Carajás (FLONA-Carajás) located in southern Pará state, Brazil, from March 30 to April 07, 2010; from September 08 to September 13, 2011; and from October 01 to October 05, 
2014. The FLONA-Carajás encompasses an area of approximately 400,000 hectares (Gumier-Costa and Sperber 2009) located on a large plateau covered by a mixture of semideciduous rain forest and, in areas of rock outcrops, scrub forest. The plateau lies within the Central Amazon province of the larger Amazonian Craton, an Archean $(2.75 \mathrm{Ga})$ tectonic area of $>4.4$ million $\mathrm{km}^{2}$ situated in northern South America (Cordani et al. 2009; Teixeira et al. 2007). It is estimated that the Serra dos Carajás, of which FLONACarajás is a part, contains the largest deposit of iron ore in the World (Cordani et al. 2009; Teixeira et al. 2007; Trendall et al. 1998). Although FLONA-Carajás is an area of environmental conservation protected by the Brazilian government, it is extensively exploited for iron ore, copper, gold, manganese, and nickel, and it is surrounded by disturbed habitat consisting of lower-elevation pastures and plantations. A detailed description of the site can be found in Gumier-Costa and Sperber (2009).

Nests of Apterostigma megacephala were located by generously spreading Cream of Rice ${ }^{\circledR}$ cereal on the leaf litter, then following bait-laden foragers returning to their nest entrances. Eighteen separate nests were located at the boundary of a small patch of secondary forest and a grasscovered clearing adjacent to a paved service road, some in the forest and some in the grass, at the Parque Zoobotânico de Carajás $\left(06.06326^{\circ} \mathrm{S} 50.05774 \mathrm{~W} \pm 5 \mathrm{~m}\right.$, elevation $658 \mathrm{~m})$. Excavations were conducted following Sosa-Calvo et al. (2015) and Schultz (1993). When a nest chamber was encountered, the fungus garden was carefully removed using a flame-sterilized spoon and/or forceps. Both ants and fungus garden were then maintained alive by placing them in plastic nest boxes with plaster-lined floors that were kept saturated with water. When the ants had reconstructed their fungus garden and removed any soil or debris that had become mixed with the garden during excavation, series of workers, alate gynes, and males, as well as portions of the gardens, were preserved in 2-ml Sartstedt micro tubes (Sartstedt Inc., Newton, NC, U.S.A.) filled with 95\% ethanol. All colonies collected in the 2010 field study were preserved in $95 \%$ ethanol after the ants reconstituted their gardens, whereas colonies collected in the 2011 and 2014 field studies were kept alive in plastic containers. Following excavation, chamber measurements were recorded.

\section{Morphology and standard measurements and indices}

Images of the worker, gyne, and male were generated in the SI NMNH Ant Lab using a JVC KY-F75U digital camera mounted on a Leica Z16 APO stereomicroscope attached to a Dell Optiplex GX620 computer. Composite images were assembled using Auto-Montage Pro® (Version 5.03.0061 BETA) software (Synoptics Ltd.). Two worker prepupae (i.e., post-feeding last-instar larvae) were dehydrated sequentially through a series of ethanol concentrations to $100 \%$ absolute and then critical point dried in a Balzers CPD-030 using liquid $\mathrm{CO}_{2}$ at the scanning electron microscopy (SEM) lab in the SI NMNH Laboratories of Analytical Biology. Once the ethanol was replaced with $\mathrm{CO}_{2}$, the samples were slowly heated to the critical point, slowly depressurized back to atmospheric pressure, dried, and mounted on aluminum stubs. The two prepared larvae were sputter-coated with $60: 40 \mathrm{wt} \%$ gold:palladium alloy on a Cressington Scientific 108 auto/SE sputter coater to a thickness of 20-25 nm. Scanning Electron Micrographs (SEMs) of these specimens were generated using a Philips XL-30 ESEM with a Lanthanum Hexaboride (LaB6) source and with a backscatter detector.

For examination of the fungal cultivar of A. megacephala, mycelia were removed from the fungus garden using sterilized needles and tweezed apart to prepare wet mounts. Two types of slide mounts were prepared: (i) fresh mounts with sterilized water and (ii) fresh mounts with lactoglycerol cotton blue as the mounting fluid. Gongylidia were examined under a compound microscope (Leica, DM750) using bright field for stained gongylidia and phase contrast for unstained gongylidia. Images were generated with a Leica ICC50-HD camera. All images were edited using Photoshop CS5® (Version 12.0) (Adobe Inc.).

Measurements are represented in $\mathrm{mm}$. Indices, abbreviations, and morphological terminology follow Gauld and Bolton (1988); Ješovnik et al. (2013); Klingenberg and Brandão (2009); Rabeling et al. (2007a); (2015); Serna and Mackay (2010); Sosa-Calvo and Schultz (2010); SosaCalvo et al. (2013); and literature cited therein, with modifications where noted. Characters and terminology used in the description of the larvae are based on Schultz and Meier (1995).

\section{Specimen deposition}

Specimens examined and specimen vouchers are deposited in the following institutions:

CRC C. Rabeling Collection, Arizona State University, Tempe, AZ, U.S.A.

DZUP Coleção Entomológica "Padre Jesus Santiago Moure", Departamento de Zoologia, Universidade Federal do Paraná, Curitiba, Paraná, Brazil.

IAvHC Departamento de Entomología, Instituto "Alexander von Humboldt," Villa de Leyva, Boyacá, Colombia.

ICN Instituto de Ciencias Naturales, Universidad Nacional de Colombia, Bogotá, Colombia. 
INPA Instituto Nacional de Pesquisas da Amazônia, Manaus, Amazonas, Brazil.

MCZC Museum of Comparative Zoology, Harvard University, Cambridge, MA, U.S.A.

MPEG Museu Paraense Emilio Goeldi, Belem, Pará, Brazil.

MZSP Museu de Zoologia, Universidade de São Paulo, São Paulo, Brazil.

MBC-UFU Universidade Federal de Uberlândia, Minas Gerais, Brazil.

USNM National Museum of Natural History, Washington, DC., U.S.A.

\section{Results}

\section{Taxonomic treatment}

\section{Apterostigma megacephala Lattke 1999}

Figures 1, 2, 3, 4, 5 and 6. Apterostigma megacephala Lattke 1999: 2, Figs. 1-4. Holotype worker: PERU, Madre de Dios, Cuzco Amazónico, 15 km NE Puerto Maldonado, Río Tambopata, 200 m, 21.vi.89, (SP Cover, JE Tobin), CA-357, Plot IE 24 [MCZC] (examined).

Geographic range Brazil (states of Pará and Mato Grosso), Colombia, and Peru; from 200 to 650 m elevation, lowland mesic forest to semi-deciduous Amazonian rain forest (Fig. 7).

Description, gyne (Fig. 2a-c)

Measurements EL 0.37-0.50; FLD 1.02-1.09; GL 2.11-2.52; HL 1.77-1.95; HFL 2.88-2.98; HTL 1.89-2.04; HW 1.64-1.71; ML 1.09-1.34; PL 0.93-1.12; PPL 0.71-0.82; PPW 0.83-0.95; SL 1.67-1.83; TL 9.49-10.7; WL 2.82-3.02; CI 88-93; MI 59-69; OI 22-29; PPI 111-133; RFLI1 54-60; RFLI2 61-64; SI 102-107 ( $n=6)$.

Similar to worker except for differences typical of caste. Head: subquadrate; in full-face view, excluding mandibles, nearly as broad as long; cephalic corners convex; cephalic margin almost straight and medially weakly emarginate. Mandibles triangular; inner (masticatory) margin of mandibles 8-9-toothed, apical and subapical teeth larger than rest; outer margin of mandibles slightly sinuous; dorsum of mandibles longitudinally striate and with appressed hairs. Clypeal apron present, shiny and horizontally striate (shared with members of $A$. pilosum group), broadly convex and interrupted medially by conspicuous projection; clypeal apron with long, thick, unpaired median setae; posterior margin of clypeus extending between frontal lobes. In lateral view, eyes large with $\sim 21$ ommatidia in longest row, surmounted on subconical tubercle as in worker. Frontal carina present but inconspicuous, blending with rugae present on head. Dorsum of head and frontal lobes rugose. Median ocellus round (width 0.073 , length $0.072 \mathrm{~mm}$ ). In lateral view, occipital collar conspicuous and subquadrate. Antennal scape surpassing occipital corner by $\sim 0.62 \mathrm{~mm}$; dorsum of antennal scape rugulose, leading edge of antennal scape with erect simple hairs, posterior margin with suberect or subdecumbent simple hairs.

Mesosoma Pronotum with reduced humeral denticles or tubercles, and pair of low lateral tubercles; dorsum of pronotum rugose; inferior corner of pronotum forming an obtuse angle, lacking tooth or spine. In lateral view, anterior margin of mesoscutum angulate; parapsidal lines conspicuous. In dorsal view, notauli as deep grooves, anterior margin of mesoscutum strongly concave. In dorsal view, mesoscutum rugose. Deep and conspicuous pits in laterodorsal margin of scutellum, connected by shallow groove. Posterior margin of scutellum with pair of blunt tubercles. In lateral view, propodeum armed with long triangular spines.

Metasoma Node of petiole vestigial, very low; in profile, rounded; in dorsal view, node with lateral shallow rugae, remainder smooth; antero-ventral portion of petiole with inconspicuous process (tooth). Postpetiole broader than long (PPL 0.71-0.82, PPW 0.83-0.95, PPI 111-133), and weakly rugose dorsally. Ventral margin of postpetiole with anterior and posterior tooth-like projections. First gastral tergite and sternite strongly rugo-reticulate, each cell with a thick suberect simple hair.

Head and dorsum of mesonotum with long simple erect hairs. Eyes, dorsum of pronotum, and sides of mesosoma with spatulate (i.e., flattened at the tip) hairs. Legs with short, subdecumbent or decumbent hairs.

Wings Forewing (length $5.7 \mathrm{~mm}$ ) smoky, with five closed cells. Area below the marginal cell with a patch (Fig. 4d), darker anteriorly and lighter apically, homologous to the fenestrae present in forewings of other Paleoattini; and as in other Paeoattini, this patch is absent in the males (Fig. 4e). Hindwing (length $4.1 \mathrm{~mm}$ ) with three closed cells and nine hamuli (Fig. 4d).

Palpal formula: 4,2 (Fig. 4c).

Description, male (Fig. 3a-c)

Measurements EL 0.41-0.69; FLD 0.43-0.47; GL 1.35-2.05; HL 1.00-1.24; HFL 2.11-2.39; HTL 1.66-1.83; HW 0.94-1.15; ML 0.40-0.57; PL 0.58-0.97; PPL 

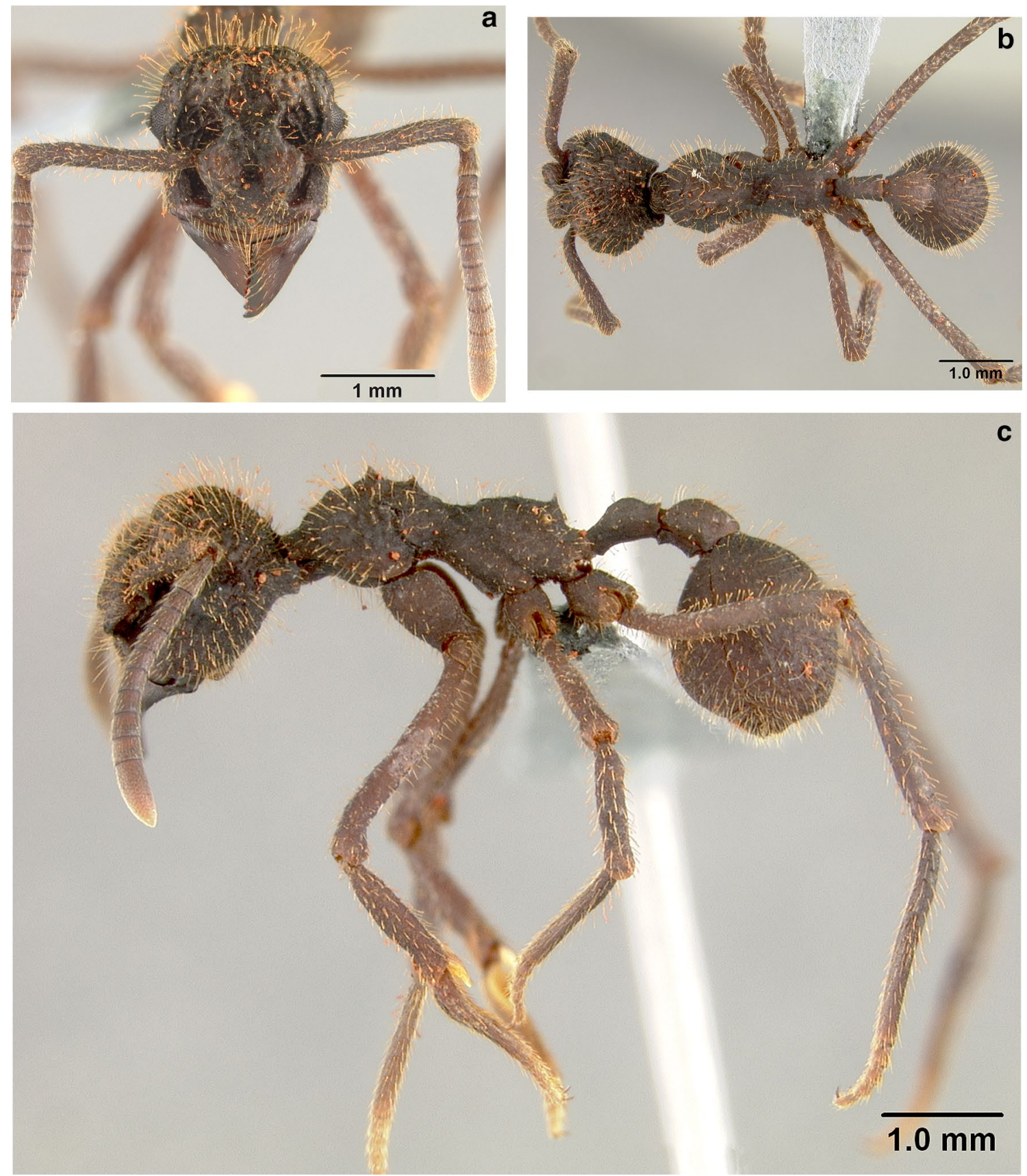

Fig. 1 Worker of Apterostigma megacephala, a full-face view, b dorsal view, $\mathbf{c}$ lateral profile

0.47-0.59; PPW 0.61-0.69; SL 0.42-0.53; TL 5.98-7.72; WL 1.88-2.45; CI 83-115; MI 34-48; OI 36-64; PPI 116-142; RFLI1 37-47; RFLI2 41-46; SI 40-48 ( $n=7)$.

Head: Dorsum rugose. In full-face view, cephalic margin convex. Inner margin of mandibles without teeth; dorsum of mandibles strongly reticulate and covered with appressed hairs. Clypeal apron thin and dorsally reticulate. Median clypeal seta long and thick (length $0.15 \mathrm{~mm}$ ), originating at the edge between the clypeal apron and the clypeus. Anterior tentorial pits conspicuous, each located in the middle of a deep groove (grooves connected by shallow depression forming posterior clypeal margin). In lateral view, frontal lobes extending forward and, in fullface view, failing to cover antennal insertions. Antennal scape thick and shorter (SL 0.42-0.53) than the length of funicular segments I-III combined (1.03-1.21 mm); dorsum of antennal scape with long, suberect simple hairs. Median ocelli rounded (width 0.08 , length $0.08 \mathrm{~mm}$ ). In lateral view, lacking hypostomal teeth. 

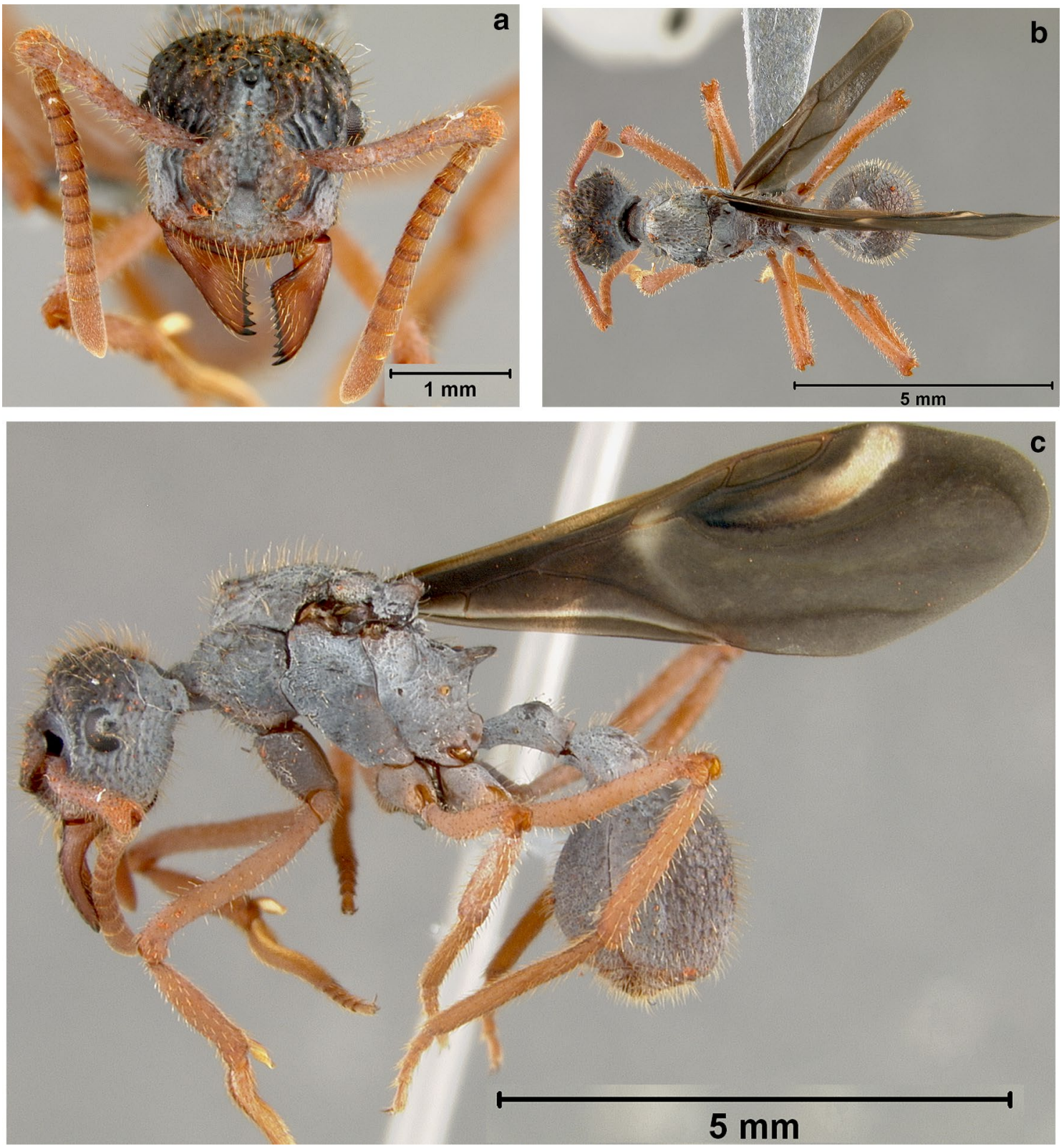

Fig. 2 Alate queen of Apterostigma megacephala, a full-face view, b dorsal view, c lateral profile

Mesosoma Pronotum lacking humeral tubercles; lateral tubercles of pronotum reduced to raised ridges. Mesonotum like that of gyne, but with posterior medial groove (seen in dorsal view). Scutellum like that of gyne. Metanotum small and smooth. Katepisternum separated from anepisternum by deep, conspicuous, groove. In profile, midposterior portion of mesonotum and scutellum somewhat raised; lateral margins smooth and somewhat shining. Dorsum of propodeum smooth and with pair of lateral carina connecting pair of long, thick, triangular propodeal spines. Declivity of propodeum smooth with thin lateral carina. Metapleural gland absent, prominent carina present instead.
Metasoma In profile, node of petiole low and convex; in dorsal view, node of petiole with thin lateral carinae and weakly concave medially. Petiolar spiracles positioned approximately equidistant between anterior and posterior ends of the petiole, conspicuously projecting and directed backwards. Anterior ventral process small, inconspicuous. Postpetiole broader than long (PPL 0.47-0.59, PPW 0.61-0.69, PPI 116-142); in lateral view, postpetiole dorsally convex; ventral margin of postpetiole with pair of conspicuous, almost equally sized, triangular teeth, one located anteriorly, another posteriorly; dorsum of postpetiole rugose. Dorsum of gaster weakly rugo-reticulate. First 

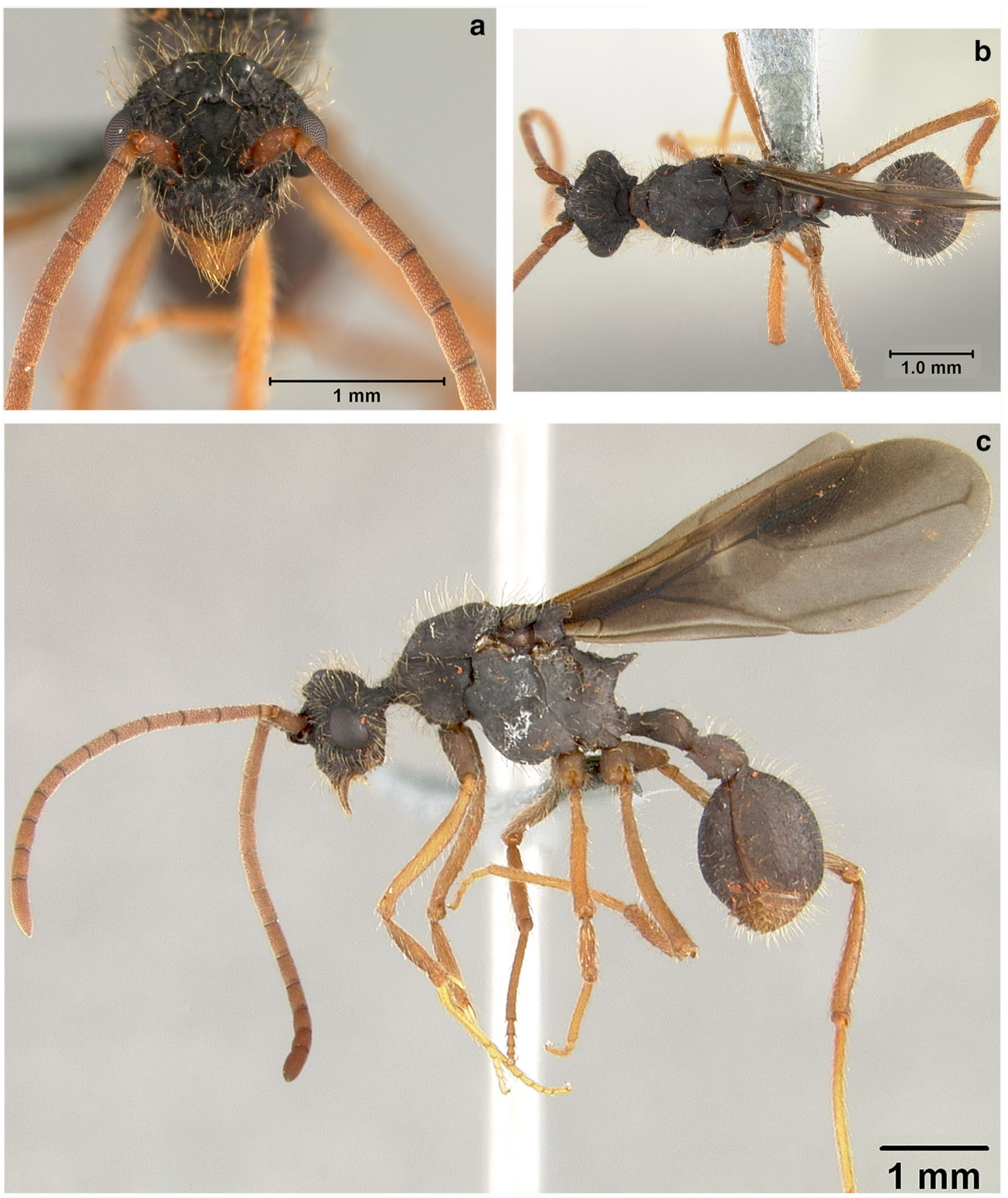

Fig. 3 Male of Apterostigma megacephala, a full-face view, b dorsal view, c lateral profile

gastral tergum with low lateral carinae that extend longitudinally almost entire length of segment; first gastral tergum covered with suberect simple hairs.

Color: Body dark brown, antennae ferrugineous, legs light ferrugineous to yellowish. Wings: Forewing (length $3.35 \mathrm{~mm}$ ) with five closed cells. Hindwing (length $2.52 \mathrm{~mm}$ ) with one closed cell and 7-9 hamuli (Fig. 4e). Both wings are slightly darker anteriorly than posteriorly, and covered with minute pubescence. The forewing of the male lacking the fenestra underneath marginal cell, differing from the forewing of the gyne.

Palpal formula: 4,2 (Fig. 4b).

Genitalia (Figs. 4f-i, 5a-e): sternum of abdominal segment IX posteriorly rounded, with a thin spiculum anteriorly (Fig. 5a); parameres long, cup-like; telomeres narrow, medially curved, and apically rounded (Figs. 4f, g, i, $5 \mathrm{c}, \mathrm{e})$; in ventral view, outer portion of telomeres with 

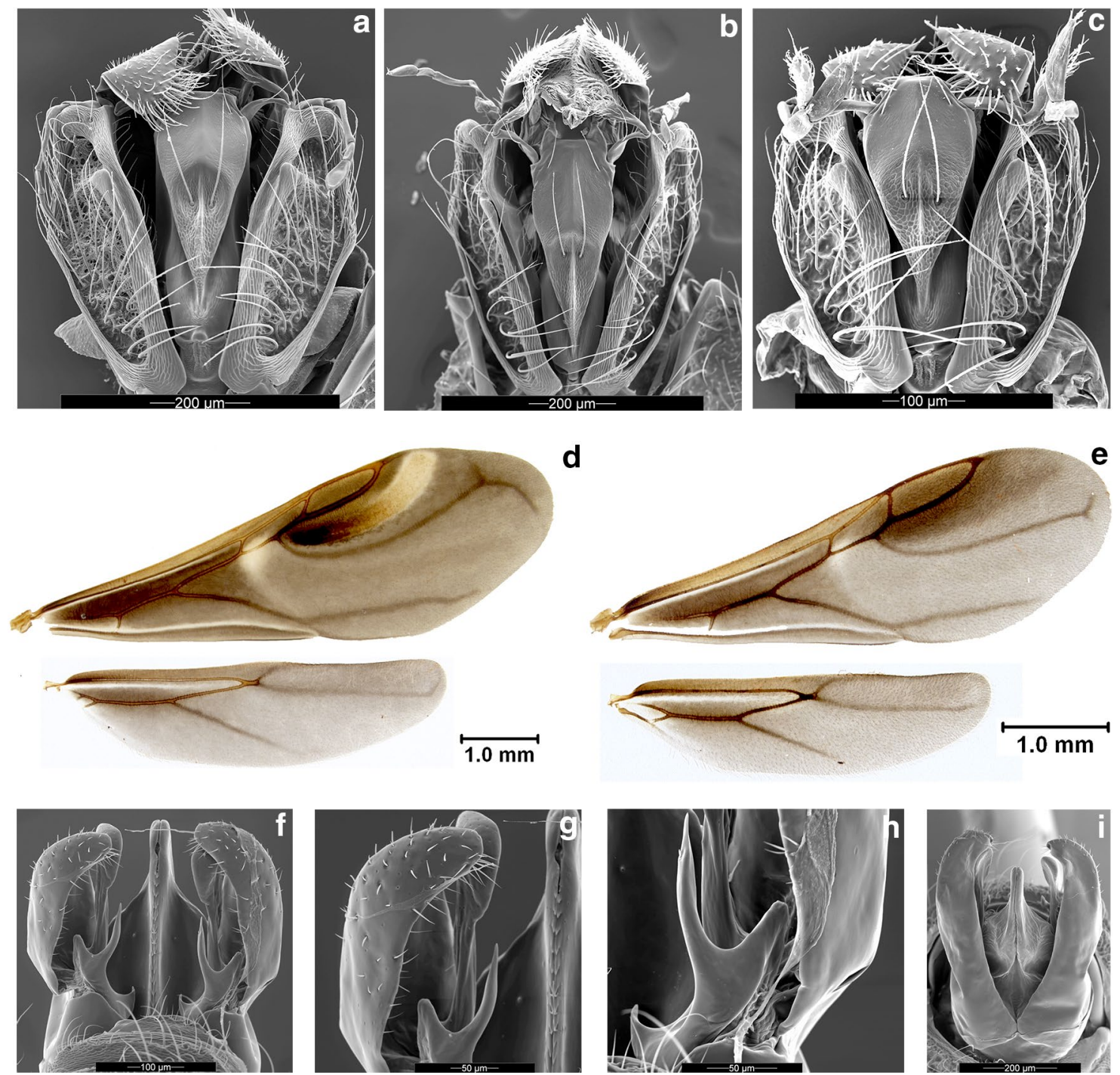

Fig. 4 Internal mouthparts of $\mathbf{a}$ worker, $\mathbf{b}$ male, and $\mathbf{c}$ queen, illustrating the 4,2 palpal formula. Fore and hind wings of $\mathbf{d}$ queen and e male. Male genitalia, $\mathbf{f}$ ventral view of genital capsule, $\mathbf{g}$ close-up

short simple hairs, inner portion with somewhat larger simple hairs (Fig. 4f, g); in dorsal view, parameres glabrous except for apical portion (Fig. 4i). In ventral view, volsella with digitus club-like (broader at apex) and with sparse foveae (Figs. 4f, g, 5c, d); cuspis with two processes, a short tooth dorsally (2) and a needle-like, long process ventrally (1), approximately half the height of the digitus (Figs. $4 \mathrm{f}-\mathrm{h}, 5 \mathrm{c}, \mathrm{d}$ ). There is, however, uncertainty regarding the homologies of these two structures; specifically, it is unclear if both are part of the cuspis. Base of volsella with an additional tooth-like process [proximal basivolsellar process (3)] (Fig. 5c, d); valviceps of penisvalve, ventrally, with 19-20 denticles (Figs. 4f, g, 5b). of paramere and volsella (cuspis and digitus), $\mathbf{h}$ close-up of digitus, composed of two processes, one needle-like and longer, the other blunt and shorter, $\mathbf{i}$ dorsal view of genital capsule

\section{Description, larva (Fig. 6a-f)}

Based on two worker prepupae from nest collection JSC110910-03. Profile "attoid" sensu Wheeler and Wheeler (1976), i.e., with a moderately curved, ventrally shortened profile (Fig. 6a); in this regard differing from most other studied Apterostigma species, including A. auriculatum, which have in common extremely curved profiles in which the ventral region is so shortened that the mouthparts are nearly in contact with the anus. As in all other Attina, thoracic-abdominal articulation absent, thoracic intersegmental constrictions superficial, deep lateral depressions associated with abdominal spiracles absent, and leg vestiges present as open slits. As in most other Attina, dorsal and lateral body surfaces devoid of setae. Ventral hair 

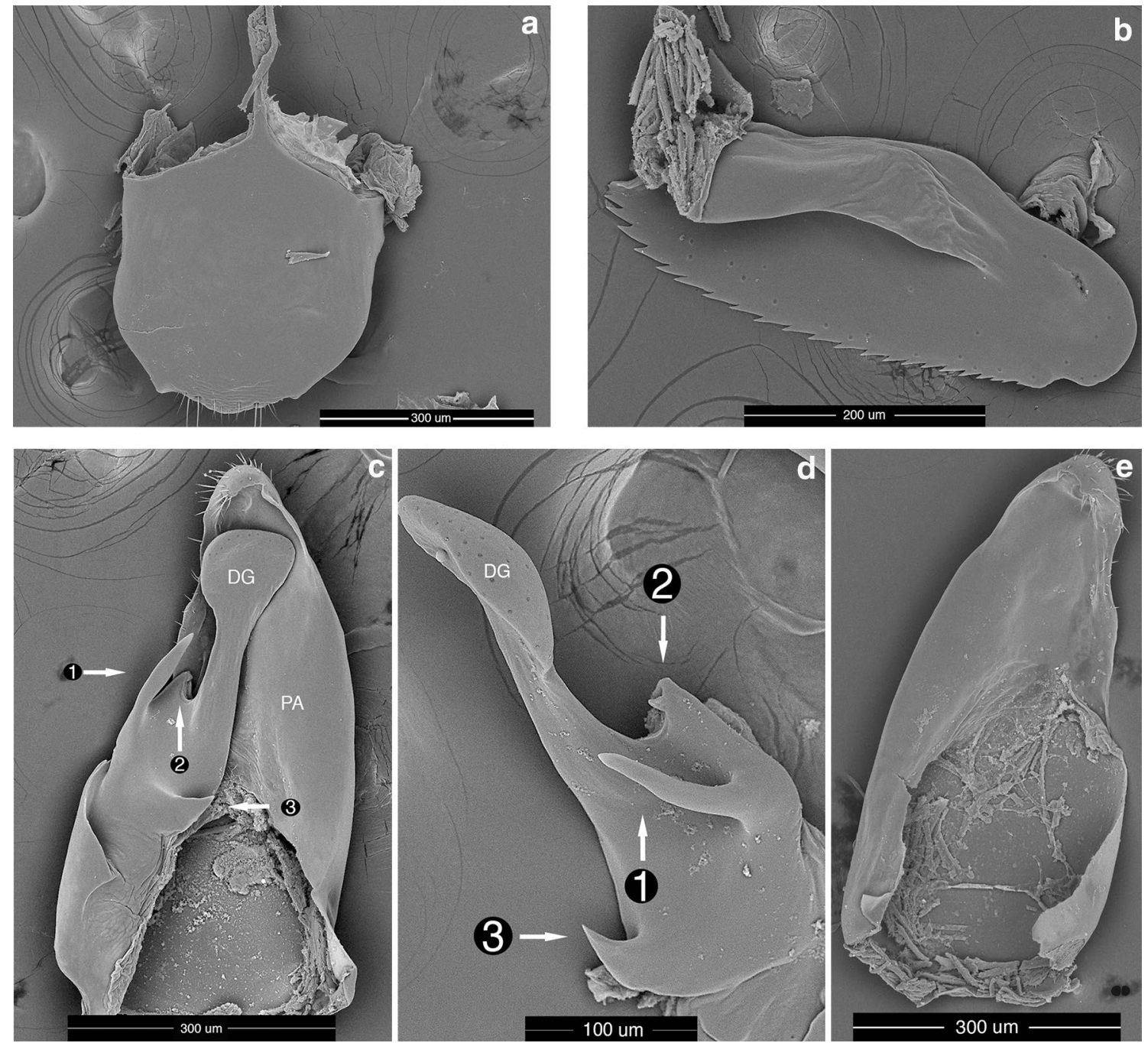

Fig. 5 Male genitalia of Apterostigma megacephala, a abdominal sternum IX, b penisvalve, $\mathbf{c}$ parameres and volsella; $\mathbf{d}$ volsella; $\mathbf{e}$ paramere. $D G$ digitus, $P A$ paramere

"feeding organ" on first thoracic segment present, but ventromedian lobe on the first thoracic segment, shared by all studied Apterostigma species except $A$. dentigerum, absent (Fig. 6b). Spinules on thoracic segment I confined to venter and mostly serrate/denticulate. Thoracic and abdominal ventromedian bosses absent. Ventral setae present on all thoracic and abdominal segments. As in other Paleoattini and in Mycetarotes species, genal lobes absent. Head with three supra-antennal setae overarching each antenna, as in other studied Apterostigma species; with two supraclypeal setae, a feature shared with Apterostigma auriculatum but absent in A. pilosum group species; and with five setae on each gena, more than in other studied Apterostigma species, which have three or four per gena. Two clypeal setae present. Two setae of uncertain homology present, one adjacent to each maxilla (Fig. 6c). Papilliform spinules present on the head on the genae and vertex, absent from the occipital area, and very sparse on the clypeus. As in other fungus-farming ants, anal setae arranged to form a basket or brush, apparently for the purpose of holding a drop of anal liquid (Lopes et al. 2005; Schneider et al. 2000), most closely conforming to the "Pheidole pattern" (Schultz and Meier 1995), with six setae ventrally and eight setae dorsally. Long and abundant ventral setae occurring on adjacent abdominal segments (Fig. 6d) may also play a role in forming the anal brush or, possibly, a food anchor, although it is difficult to imagine how the larva could be capable of flexing its head far enough posterad to feed on any fungal hyphae positioned in this region. Ventral anal lip absent. Labrum monolobate, narrow, and bulging, a synapomorphy for the fungus-farming ants; at least four anterior labral setae present, setiform. Mandibles fleshy and subconical as in other Attina, but unusually long and protruding and with the tips noticeably curved anterad (Fig. 6b); differing 

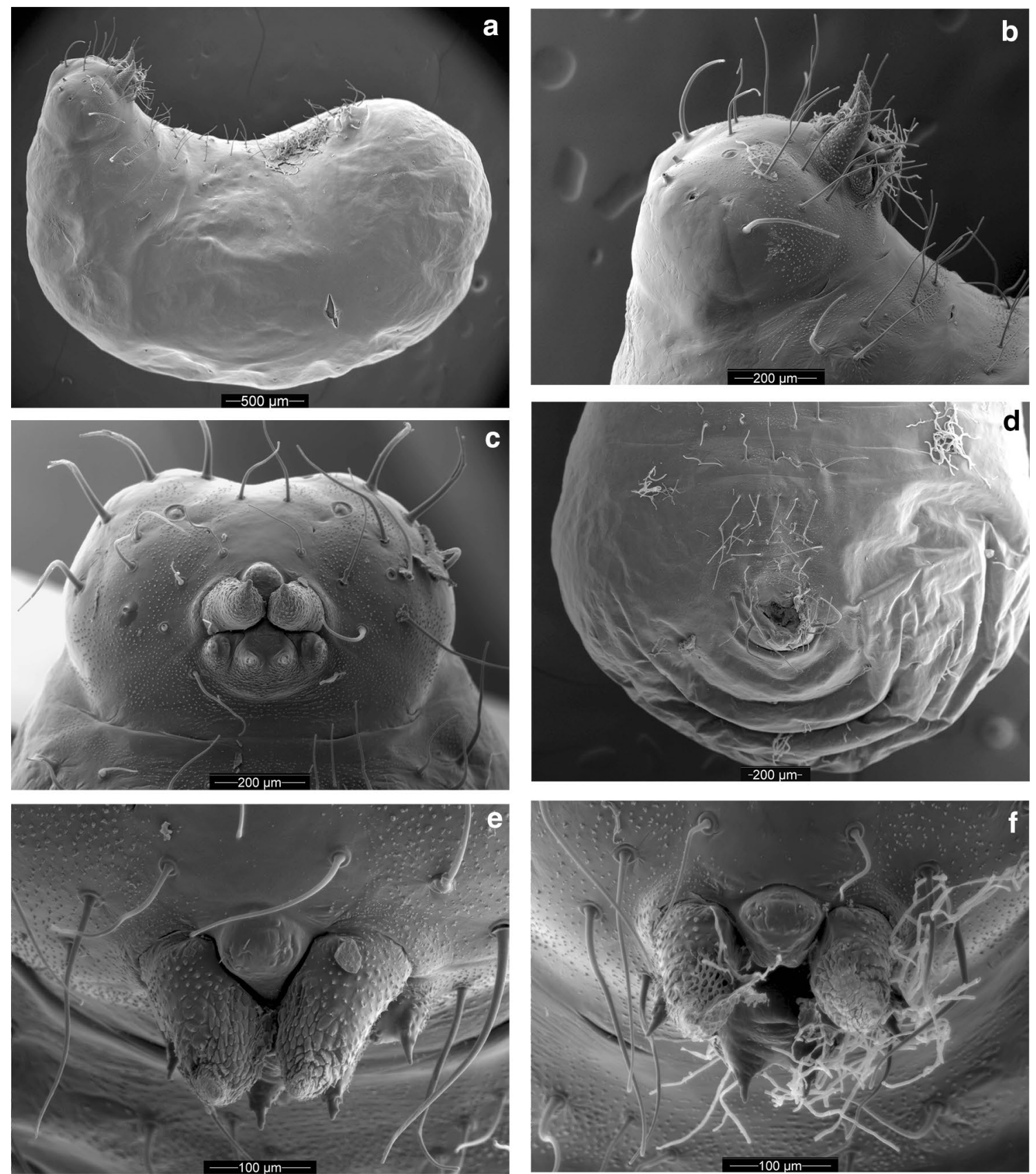

Fig. 6 Larva of Apterostigma megacephala, a lateral profile, b head in lateral view, $\mathbf{c}$ head in full-face view, $\mathbf{d}$ anal region in ventral view, e mandibles in dorsal view, $\mathbf{f}$ mandibles in dorsal view with mycelium present

from all other known Apterostigma species larvae, which have very short mandibles. A distinct, undivided apical mandibular tooth and no subapical teeth; spinules densely distributed on the distal half of the mandibles, particularly medially; less densely in the proximal half (Fig. 6e); differing markedly from $A$. auriculatum, which has no spinules on the mandible, and from most studied A. pilosum group species (including $A$. dentigerum and A. mayri, but not A. collare), which lack spinules on the mandibular apex.
Mandibular gnathobases absent (present only in Mycocepurus species). Basal portions of maxillae fused with head capsule. As in other Paleoattini, maxillary palp and galea closely approximated (Fig. 6c). Galea reduced, as in other attines. Maxillary palp strikingly digitiform (Fig. 6e), in this way differing from all other Apterostigma species, for which a reduced maxillary palp is a synapomorphy, but resembling the condition in other attines, particularly other paleoattines. Maxillary accessory palpal sensillum 


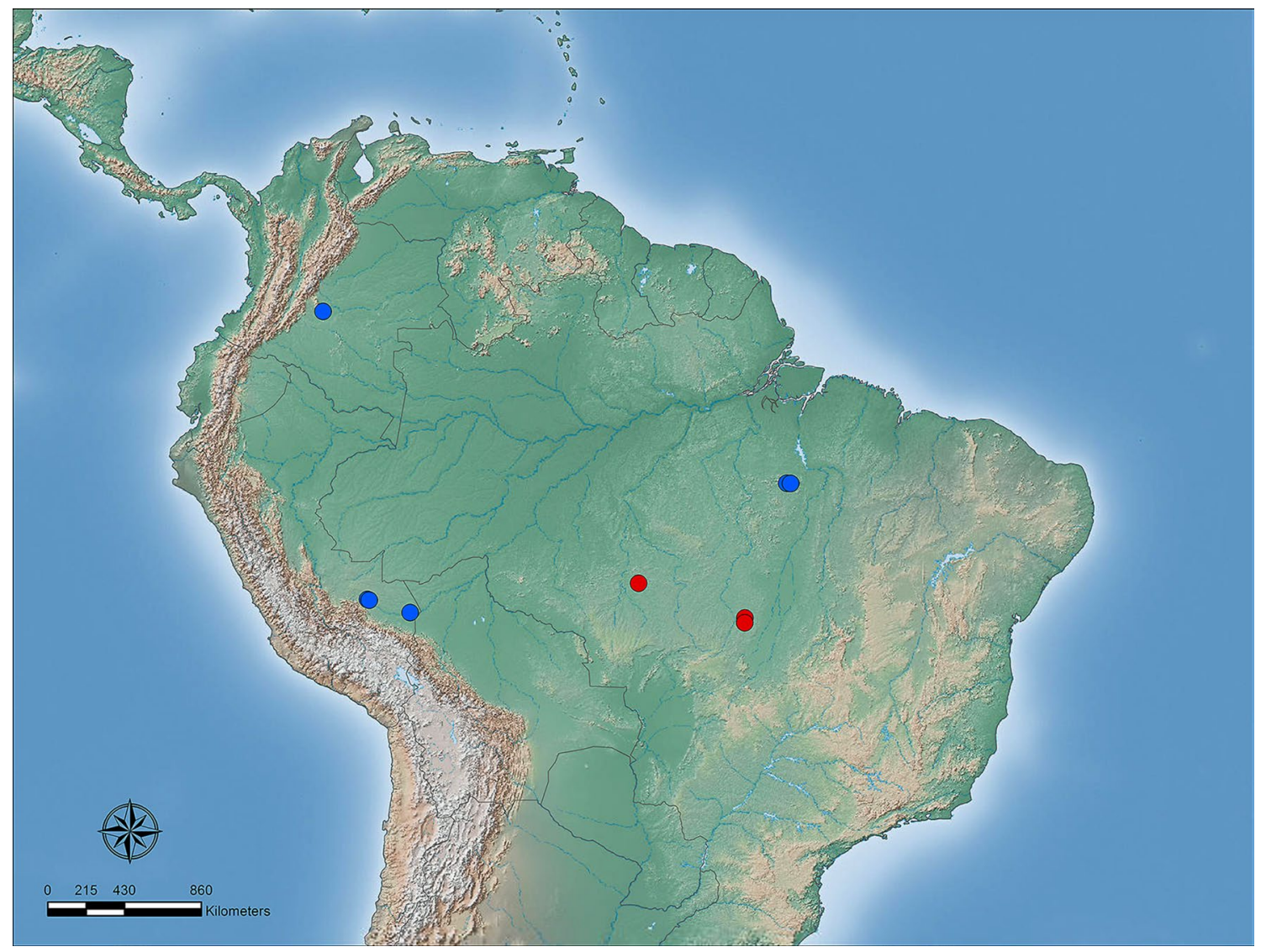

Fig. 7 Known distribution of Apterostigma megacephala in (blue circles) Serrania de La Macarena, Colombia; Madre de Dios, Peru; and Floresta Nacional de Carajás, Pará, Brazil; and (red circles, new records) Mato Grosso, (Canarana and Juara), Brazil. (Color figure online)

not observed. Maxillary setae apparently absent unless the two setae of uncertain homology mentioned above, each adjacent to a maxilla (Fig. 6c), are homologous with those occurring laterally on the maxillae of Mycocepurus species, one on each maxilla in $M$. smithii and two on each maxilla in M. goeldii (Schultz and Meier 1995). Labium very unusual for an attine, bilobed, and strongly protruding and with long, digitiform labial palps (Fig. 6f), most similar to the form observed in some Myrmicocrypta and Mycocepurus species rather than in other Apterostigma species. Labial spinules absent or nearly absent both basad and distad of the sericteries, suggesting that, unlike in other Apterostigma species, the mandibles are the primary organs employed in fungal maceration. Hypopharyngeal spinules unobservable.

\section{Material examined}

BRAZIL: Pará, Parauapebas, Floresta Nacional de Carajás, Parque Zoobotánico; $658 \mathrm{~m} ; 50.05777^{\circ} \mathrm{W}, 6.06323^{\circ} \mathrm{S}$; 13.ii.2009, (CT Lopes \& J Sosa-Calvo), forest edge, worker foraging on leaf litter, JSC090213-01; same locality as previous entry, but 1.iv.2010, (TR Schultz, $J$ Sosa-Calvo, CT Lopes), nest series, forest edge, in ground, fungus garden, TRS100401-09; TRS100401-10; same locality as previous entry, but $672 \mathrm{~m}, 50.05774^{\circ} \mathrm{W}$, 6.06321 ${ }^{\circ} \mathrm{S}$, 2.iv.2010, ( $\mathrm{J}$ Sosa-Calvo, TR Schultz, CT Lopes), nest series, forest edge, in ground, fungus garden, TRS100402-02; same locality as previous entry, but $663 \mathrm{~m}, 50.05762^{\circ} \mathrm{W}, 6.06313^{\circ} \mathrm{S}, 2.1 \mathrm{v} .2010$, (CT Lopes, TR Schultz, J Sosa-Calvo), nest series, forest edge, in ground, fungus garden, TRS100402-03; same locality as previous entry, but $650 \mathrm{~m}, 50.05781^{\circ} \mathrm{W}, 6.06325^{\circ} \mathrm{S}, 2.1 \mathrm{v} .2010$, (J. Sosa-Calvo, TR Schultz, CT Lopes), nest series, $2^{\circ}$ forest edge, in soil, JSC100402-11; same as previous entry, but $659 \mathrm{~m}, 50.05758^{\circ} \mathrm{W}, 6.0632^{\circ} \mathrm{S}, 2 . \mathrm{iv} .2010$, $(J$. Sosa-Calvo, TR Schultz, CT Lopes), nest series, $2^{\circ}$ forest edge, under ground, JSC100402-12; same as previous entry, but $641 \mathrm{~m}, 50.05785^{\circ} \mathrm{W}, 6.06321^{\circ} \mathrm{S}, 10.1 x .2011$, (J. Sosa-Calvo, CT Lopes), nest series, forest edge, under ground, [=CTL110910-01] JSC110910-01; JSC11091004; JSC110910-05; same as previous entry, but $676 \mathrm{~m}$, $50.05776^{\circ} \mathrm{W}, 6.06321^{\circ} \mathrm{S}, 10 . i x .2011$, (J. Sosa-Calvo, CT Lopes), nest series, $2^{\circ}$ forest edge, in soil, JSC110910-03; 
JSC110911-16; JSC110912-02; CTL110911-01; same as previous entry, but $12 . i x .2011$, nest series, $2^{\circ}$ forest edge, leaf litter/soil interface, JSC110912-03; same as previous entry, but $632 \mathrm{~m}, 50.05761^{\circ} \mathrm{W}, 6.06321^{\circ} \mathrm{S}, 2 . x .2014$, (J Sosa-Calvo, TR Schultz, A Ješovnik, CT Lopes), nest series, forest edge, under ground, JSC141002-04; JSC141002-06; TRS141002-02; Mato Grosso, 70 km from Canarana, $390 \mathrm{~m}, 52.38068^{\circ} \mathrm{W}, 13.07660^{\circ} \mathrm{S}$, vii.2013, (L Paolucci \& ML Bicalho); Juara, [350 m], $57.7184861^{\circ} \mathrm{W}$ $11.0902028^{\circ} \mathrm{S}$, ii.2015, (RCL Santos) [not examined].

\section{Natural history}

\section{Macrohabitat and foraging behavior}

Specimens of Apterostigma megacephala have been collected in lowland (from 200 to $350 \mathrm{~m}$ elevation) mesic forests of Colombia and Peru (Lattke 1999). In the Floresta Nacional de Carajás (FLONA-Carajás) in Pará, Brazil, we collected this species at relatively higher elevation $(650 \mathrm{~m})$ in semi-deciduous, Amazonian rain forest. Recently, five workers of A. megacephala were collected in Winkler leaflitter samples in patches of lowland forest $(390 \mathrm{~m})$ in Mato Grosso state, Brazil (J Chaul, pers. comm.).
Field observations suggest that workers of Apterostigma megacephala forage individually for substrate (Fig. 8a, b), which consists of insect frass and small inflorescences. Individuals observed in FLONA-Carajás were carrying leaflets, probably of Newtonia suaveolens (Fabaceae), into their nests, but the leaflets were not incorporated into their fungus gardens. Instead, they were used to line the garden chamber floors. In the field, workers of A. megacephala resemble workers of species of the ant genus Ectatomma Smith in size, behavior, and superficial habitus. When workers are disturbed, they feign death and remain motionless for a few minutes, then return to normal activity. Workers of A. megacephala seemed to be more active during the afternoon hours. In the study area, a dense layer of leaf litter had accumulated at the boundary of the forest and the grassy area. Individual foragers were far more conspicuous when this layer of leaf litter was removed.

\section{Nest architecture}

Nest entrances of Apterostigma megacephala consist of an irregular hole in the ground, $\sim 2 \mathrm{~cm}$ wide, hidden under a thick layer of leaf litter. Eighteen colonies of Apterostigma megacephala were excavated and censused (Table 1). Nests consisted of a relatively shallow single chamber located from $<1$ to $16.5 \mathrm{~cm}$ below the surface (Table 1).
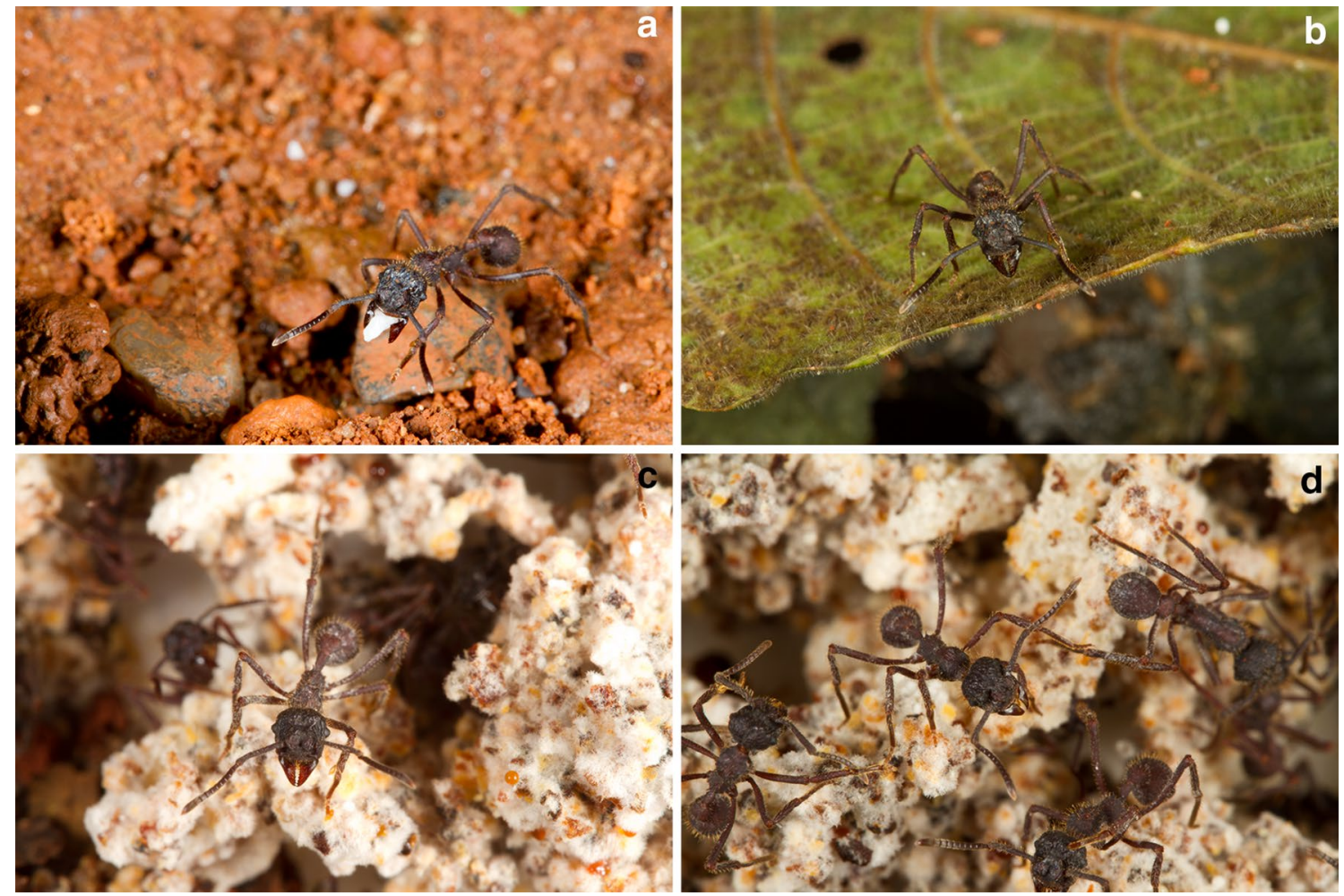

Fig. 8 Workers of Apterostigma megacephala $\mathbf{a}, \mathbf{b}$ foraging in leaf litter and $\mathbf{c}, \mathbf{d}$ tending their fungus garden 
Nest chambers were subspherical and measured 5-20 cm in diameter and 3.5-9.5 cm in height. They contained the fungus garden, workers, brood, queen and, in some cases, alate reproductives (Fig. 8c, d), which, based on collections made both in April and September, seem to be produced continuously throughout the year (Table 1). Nests of Apterostigma megacephala excavated in or near the grassy area with little $(<2 \mathrm{~cm}$ thick) leaf litter were consistently deeper than those excavated in forest fragments where the leaf-litter layer was $\sim 20$-cm thick. The ceilings of the chambers were usually covered with rootlets from which the garden was suspended. The floors of the chambers were usually covered with the previously mentioned small, uncut leaflets brought in by the workers, probably of Newtonia suaveolens (Fabaceae); however, these leaflets were never observed to be incorporated into the gardens.

\section{Fungus gardens}

Apterostigma megacephala cultivates the leaf-cutting ant fungal symbiont Leucoagaricus gongylophorus and all examined gardens possessed gongylidia [nutritious swollen hyphal tips; (Fig. 9b, d)], known to consistently occur in the obligate fungal symbionts of higher-attine ants in the genera Trachymyrmex, Sericomyrmex, Acromyrmex, and Atta (Fig. 9a, c) (De Fine Licht et al. 2014). Rarely, gongylidia occur in the fungus gardens of lower-attine ants, but the fungi are distantly related to L. gongylophorus and the convergent occurrence of gongylidia is not fully understood (Masiulionis et al. 2014). The consistent occurrence of gongylidia in the gardens of A. megacephala is consistent with the discovery that it is the only lower-attine ant known to cultivate a higher-attine fungus.

\section{Demography}

Colonies of Apterostigma megacephala are relatively small, containing less than 100 workers (Table 1). Dealate queens were found in 13 out of the 18 colonies excavated. When a colony was disturbed in the course of the excavation, the queen was observed to quickly escape from the nest, a frequent observation in nest excavations of the socalled "lower" fungus-farming ants (Rabeling et al. 2007b). Therefore, queen escape is the probable explanation for the five queenless colonies. All queen-right nests consistently contained a single queen, and therefore colonies of A. megacephala can be considered monogynous (Table 1). Brood was encountered in all colonies but brood demographics are reported here only for the colonies collected in April 2010 , which were preserved directly into $95 \%$ ethanol. The colonies collected in September 2011 and October 2014 were maintained alive in artificial plastic nests [following Sosa-Calvo et al. (2015) and Schultz (1993)]. Alate queens and males were found in 10 out of 18 colonies collected both during the rainy season (December to April) and the dry season (June to October). Colonies maintained alive in the laboratory continued to sporadically produce alate reproductives.

\section{Ant morphology}

Morphologically, Apterostigma megacephala possesses a unique combination of character states from the two main species groups (auriculatum and pilosum) within the genus Apterostigma. For example, it possesses the presumably plesiomorphic shining border of the clypeal apron found in the A. pilosum but absent in the A. auriculatum species group, whereas it possesses the more pronounced sculpture typical of the A. auriculatum species group. In some character states, however, A. megacephala differs from all other Apterostigma species. For example, all other known species in the genus Apterostigma have a palpal formula of 3,2, whereas A. megacephala (Fig. 4a-c) retains the ancestral attine condition of 4,2 . (This corrects the palp formula reported for A. megacephala by Lattke (1999), who, due to the few specimens available to him at the time of his study, was unable to perform dissections.) The reduced palpal formula in Apterostigma has previously been considered to be a synapomorphy for the genus, convergently derived in the distantly related social parasites Pseudoatta argentina and Mycocepurus castrator (Lattke 1999; Rabeling and Bacci 2010; Schultz 2007).

\section{Molecular characters}

All other Apterostigma species for which DNA sequence data are available have a unique codon deletion at position corresponding to site 473 in the Apis mellifera mitochondrial cytochrome c oxidase 1 (COI) gene (Genbank accession number KJ396181) (Schultz 2007), whereas A. megacephala retains the ancestral condition in which the codon is present.

\section{Discussion}

The relict species Apterostigma megacephala is a plesiomorphic fungus-farming ant, i.e., it retains a suite of character states that are believed to be ancestral to all fungusfarming ants, including pronounced sculpture (retained in the A. auriculatum group but vestigial in the A. pilosum group); palpal formula 4,2 (3,2 in all other Apterostigma species, shared with most other attine ants); distal margin of the clypeal apron smooth and shining (lost in the $A$. auriculatum group); head quadrate (head narrowed posteriorly in all other Apterostigma species); larval maxillary 
Table 1 Nest measurements and colony demographics of 18 excavated nests of Apterostigma megacephala in Floresta Nacional de Carajás (FLONA-Carajás)

\begin{tabular}{|c|c|c|c|c|c|c|c|c|c|}
\hline \multirow[t]{2}{*}{ Nest } & \multirow[t]{2}{*}{ Locality } & \multirow[t]{2}{*}{ Coll. code } & \multirow[t]{2}{*}{ Date } & \multirow[t]{2}{*}{ Chamber no. } & \multirow[t]{2}{*}{ Depth $(\mathrm{cm})$} & \multicolumn{3}{|c|}{$\begin{array}{l}\text { Chamber dimensions } \\
(\mathrm{cm})\end{array}$} & \multirow[t]{2}{*}{ Notes } \\
\hline & & & & & & Height & Width & Depth & \\
\hline 1 & FLONA & TRS100401-09 & April 01, 2010 & 1 & NA & NA & NA & NA & $\begin{array}{l}\text { Chamber encountered by accident. } \\
\text { 29w, 2ag, 3L, and garden present. } \\
\text { In addition, } 1 \text { snail shell and bee } \\
\text { head. Queen present }\end{array}$ \\
\hline 2 & FLONA & TRS100401-10 & April 01, 2010 & 1 & $\sim 5$ & 6 & 8.5 & NA & $\begin{array}{l}\text { Nest chamber was located in loose } \\
\text { rootlet layer. } 71 \mathrm{w}, 2 \mathrm{ag}, 3 \mathrm{~m}, 8 \mathrm{~L} \text {, } \\
\text { 31p, 10e. Queen present }\end{array}$ \\
\hline 3 & FLONA & TRS100402-02 & April 02, 2010 & 1 & 3 & 7.5 & 11.5 & 7 & $\begin{array}{l}\text { Garden hanging from rootlets. } \\
\text { Sides of chamber lined with small } \\
\text { leaflets (Newtonia suaveolensis). } \\
\text { Large colony: } 50 \mathrm{w}, 3 \mathrm{ag}, 4 \mathrm{~m}, 10 \mathrm{~L} \text {, } \\
\text { 10p, 11e. Queen not found }\end{array}$ \\
\hline 4 & FLONA & TRS100402-03 & April 02, 2010 & 1 & 3 & 7 & 11 & NA & $\begin{array}{l}\text { Chamber ovate. Garden suspended } \\
\text { from roots. Large colony: 68w, } \\
\text { 7ag, } 14 \text { m, 41L, 25p, 35e. Queen } \\
\text { not found. One Strumygenys sp } \\
\text { worker in garden }\end{array}$ \\
\hline 5 & FLONA & JSC100402-11 & April 02, 2010 & 1 & $<1$ & 9.5 & 11 & 5 & $\begin{array}{l}16 \mathrm{w}, 2 \mathrm{~L}, 1 \mathrm{p}, 4 \mathrm{e} . \text { Males and queen } \\
\text { absent }\end{array}$ \\
\hline 6 & FLONA & TRS100402-12 & April 02, 2010 & $1 ?$ & NA & NA & NA & NA & $\begin{array}{l}\text { Encountered by accident. Medium- } \\
\text { sized colony: 39w, 3ag, } 7 \text { m, 4L, } \\
\text { 19e. Queen present }\end{array}$ \\
\hline 7 & FLONA & JSC110910-01 & September 10, 2011 & 1 & $\sim 6$ & 7 & 7 & 11 & $\begin{array}{l}\text { Rounded chamber. Several workers } \\
\text { were collected. Queen present }\end{array}$ \\
\hline 8 & FLONA & JSC110910-03 & September 10, 2011 & 1 & 16.5 & 6 & 10 & 12.5 & $\begin{array}{l}\text { Large nest chamber. Fungus garden } \\
\text { hanging from rootlets at the } \\
\text { ceiling of chamber. Bottom of } \\
\text { chamber covered with leaflets } \\
\text { (Newtonia suaveolensis) and other } \\
\text { dry leaf-litter material. The nest } \\
\text { chamber was located approxi- } \\
\text { mately } 45^{\circ} \text { from nest entrance. } \\
\text { 1ag, } 2 \mathrm{~m} \text {. Queen present }\end{array}$ \\
\hline 9 & FLONA & JSC110910-04 & September 10, 2011 & 1 & 4 & 6 & 6 & 10 & $\begin{array}{l}\text { Small rounded chamber. Nest cham- } \\
\text { ber located underneath a big root. } \\
\text { The ceiling of the chamber with } \\
\text { abundant rootlets and the garden } \\
\text { seeming to hang from them. Floor } \\
\text { of chamber flattened and with } \\
\text { dry pieces of leaf litter. No alates } \\
\text { found. Queen present }\end{array}$ \\
\hline 10 & FLONA & JSC110910-05 & September 10, 2011 & 1 & NA & 6 & 5 & 20 & $\begin{array}{l}\text { Rounded chamber. Chamber located } \\
\text { underground immediately below } \\
\text { leaf litter. Ceiling of chamber with } \\
\text { lots of rootlets. Queen present }\end{array}$ \\
\hline 11 & FLONA & JSC110911-15 & September 10, 2011 & 1 & 7 & 4 & 8 & 18.5 & $\begin{array}{l}\text { Large nest chamber. Ceiling of } \\
\text { chamber covered by rootlets. Fun- } \\
\text { gal cultivar hanging from rootlets } \\
\text { in ceiling. Thick layer }(\sim 20 \mathrm{~cm}) \\
\text { of leaf litter above soil. } 3 \mathrm{ag}, 4 \mathrm{~m} \text {. } \\
\text { Queen present }\end{array}$ \\
\hline 12 & FLONA & JSC110911-16 & September 10, 2011 & 1 & 2 & 4 & 6 & 10 & $\begin{array}{l}\text { Small chamber and colony. Ceiling } \\
\text { of chamber covered with rootlets. } \\
1 \mathrm{~m} \text {. Queen present }\end{array}$ \\
\hline
\end{tabular}


Table 1 (continued)

\begin{tabular}{|c|c|c|c|c|c|c|c|c|c|}
\hline \multirow[t]{2}{*}{ Nest } & \multirow[t]{2}{*}{ Locality } & \multirow[t]{2}{*}{ Coll. code } & \multirow[t]{2}{*}{ Date } & \multirow[t]{2}{*}{ Chamber no. } & \multirow[t]{2}{*}{ Depth $(\mathrm{cm})$} & \multicolumn{3}{|c|}{$\begin{array}{l}\text { Chamber dimensions } \\
(\mathrm{cm})\end{array}$} & \multirow[t]{2}{*}{ Notes } \\
\hline & & & & & & Height & Width & Depth & \\
\hline 13 & FLONA & CTL110911-01 & September 10, 2011 & 1 & 3 & 8 & 9 & 9 & $\begin{array}{l}\text { Medium-sized chamber. Queen not } \\
\text { collected }\end{array}$ \\
\hline 14 & FLONA & JSC110912-01 & September 10, 2011 & 1 & 4 & 5 & 9 & 11 & $\begin{array}{l}\text { Large rounded nest chamber. Ceil- } \\
\text { ing of chamber with abundant } \\
\text { rootlets; chamber floor flattened } \\
\text { and with several leaf pieces and } \\
\text { dry leaf litter. 5ag. Queen present }\end{array}$ \\
\hline 15 & FLONA & JSC110912-03 & September 10, 2011 & 1 & NA & 5 & 16 & 10.5 & $\begin{array}{l}\text { Large nest chamber located under- } \\
\text { neath leaf litter-soil interface. } \\
\text { Garden hanging from rootlets in } \\
\text { the ceiling. } 4 \mathrm{~m} \text {. Queen present }\end{array}$ \\
\hline 16 & FLONA & JSC141002-04 & October 02,2014 & 1 & NA & 3.5 & 13 & 5 & $\begin{array}{l}\text { Large nest chamber located under- } \\
\text { neath leaf litter and soil layer. No } \\
\text { alates present. Several workers } \\
\text { and brood. Queen present }\end{array}$ \\
\hline 17 & FLONA & JSC141002-06 & October 02, 2014 & 1 & NA & 4 & 10 & 5 & $\begin{array}{l}\text { Large, very shallow chamber. } \\
\text { Chamber located between the } \\
\text { leaf litter and soil layers. Garden } \\
\text { suspended from rootlets and } \\
\text { bottom of chamber covered with } \\
\text { small leaves }\end{array}$ \\
\hline 18 & FLONA & TRS141002-02 & October 02,2014 & 1 & 5 & 7 & 11 & 8 & $\begin{array}{l}\text { Large nest chamber. Chamber lined } \\
\text { with leaflets from a legume tree, } \\
\text { probably Newtonia suaveolensis. } \\
\text { No alates present. Queen present }\end{array}$ \\
\hline
\end{tabular}

$a g$ alate gyne, $e$ eggs, $L$ larvae, $m$ male, $p$ pupae, $w$ worker

palp digitiform (reduced in all other Apterostigma species); larval labial palp digitiform (lost in all other Apterostigma, but shared with some other Paleoattini); larval profile moderately curved ["attoid" of Wheeler and Wheeler (1976)] (extremely curved in all other Apterostigma species); and mitochondrial COI DNA sequence with a codon triplet present in all other known ants, including non-attine ants, but absent in all other Apterostigma species. In addition, $A$. megacephala possesses a number of unique, derived character states, most notably the cultivation of Leucoagaricus gongylophorus, otherwise cultivated only by some species in the leaf-cutting ant genera Acromyrmex and Atta (Schultz et al. 2015).

The biological constraints enforcing strong symbiont fidelity at the level of the five attine agricultural systems demonstrably do not apply to A. megacephala. Although the constraints remain unknown, it is plausible that they are associated with a primitive retention of nutritional independences that have been lost in other fungus-farming ants. An example of such a nutritional independence is the ability to synthesize the amino acid arginine, which is present in all ants for which genomic data are available with the notable exception of fungus-farming ants, which lack two of the enzymes (argininosuccinate lyase and argininosuccinate synthase) in the arginine synthesis pathway, presumably creating a nutritional dependence on their fungal cultivars for this amino acid (Ješovnik et al. 2016; Nygaard et al. 2016; Nygaard et al. 2011; Suen et al. 2011). The absence of argininosuccinate lyase and argininosuccinate synthase in A. megacephala indicates that this loss happened early in the evolution of attine ants and that it might have been one of the factors causing the ants to become obligate symbionts, dependent on the fungus. If similar nutritional dependences (or, in the case of higherattine agriculture, co-dependences) are responsible for the symbiont fidelity characterizing each of the five attine agricultural systems, then perhaps A. megacephala, although also presumably unable to synthesize arginine (Ješovnik et al. 2016), otherwise retains a primitive ability to utilize a wide range of fungi. If so, and if the recently evolved L. gongylophorus provides A. megacephala with a fitness advantage relative to lower-attine fungi, then perhaps $A$. megacephala has been able to take advantage of $L$. gongylophorus in a way that all other lower-attine as well as many other higher-attine ants cannot.

Further study of A. megacephala at Carajás, as well as at the other localities where it is known to occur, may provide important insights into our broader understanding of 
Fig. 9 Nutritious swollen hyphal tips (gongylidia) typical of higher-attine fungal cultivars, a, c gongylidia of L. gongylophorus from the fungus garden of an Atta sp., b, d gongylidia of $L$. gongylophorus from the fungus garden of Apterostigma megacephala. a, b Gongylidia not stained, c, d gongylidia stained with lactoglycerol cotton blue
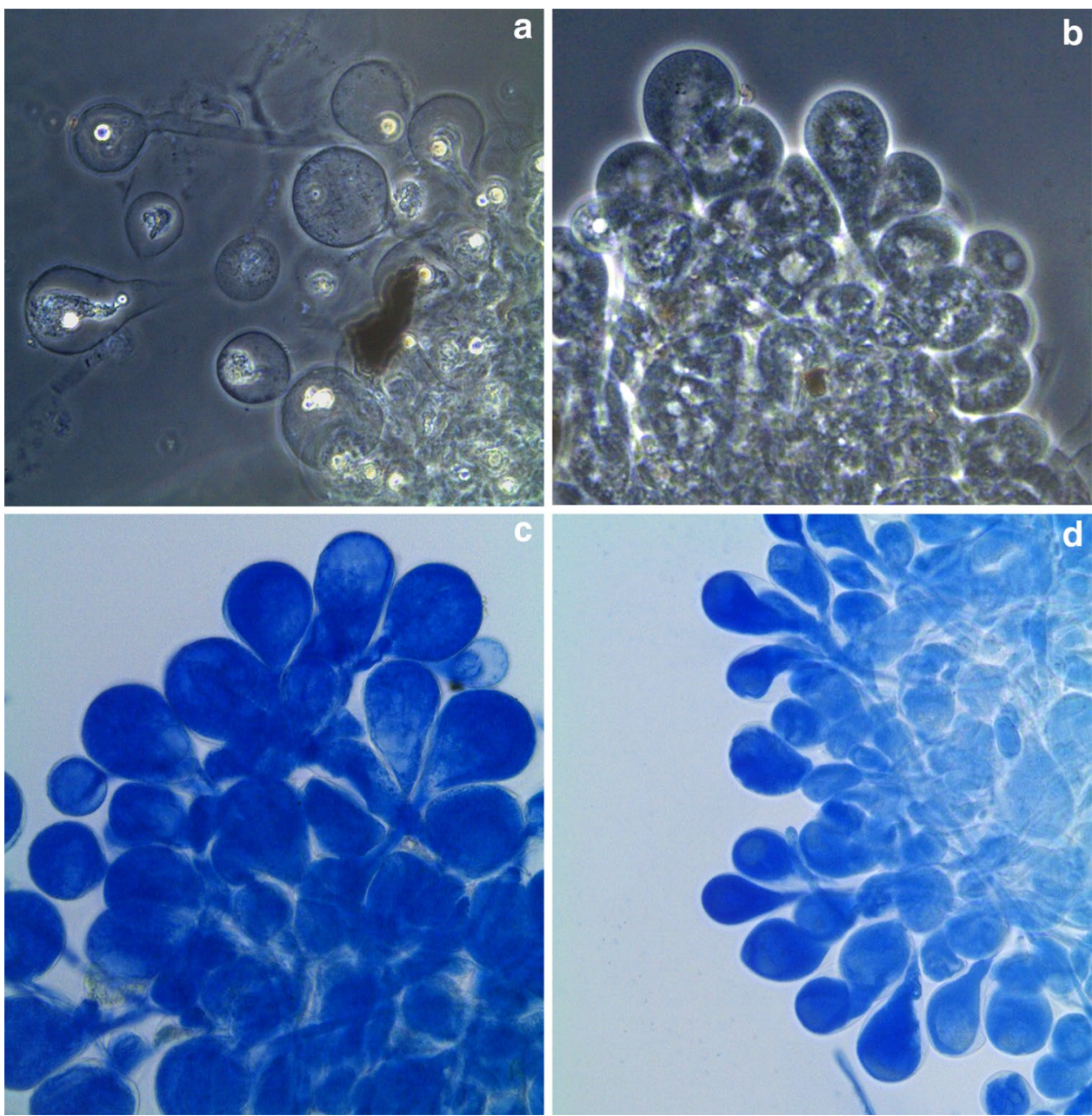

the biological mechanisms that constrain symbiont fidelity in the five attine agricultural systems. If A. megacephala is consistently found to cultivate $L$. gongylophorus wherever it occurs, this would indicate that, since the association began, it has become obligate, whereas variation in cultivar association across localities would indicate that $A$. megacephala is able to utilize both lower- and higher-attine fungi for food, making it unique among known fungusfarming ants.

Acknowledgements We are grateful to R. C. F. Brandão and R. Rosa da Silva for information about Apterostigma megacephala in Carajás; to T. Izzo for information about A. megacephala in Juara, Mato Grosso; to J. Chaúl (Universidade Federal de Viçosa) for information regarding collections of A. megacephala in Canarana, Mato Grosso; to F. Drumond Martins and E. Esteves of Instituto Chico Mendes de Conservação da Biodiversidade (ICMBio) at Floresta Nacional de Carajás for their help and guidance; to E. Okonski (NMNH) for collections and research support; to S. Messer (University of Rochester) for help with the description of the male genitalia, and to S. Whittaker (NMNH) for help with preparation of the larvae. This manuscript was greatly improved thanks to comments from Terry McGlynn and two anonymous reviewers. For permission to conduct field research, we thank the Conselho Nacional de Desenvolvimento Científico e Tecnológico (CNPq; Processo EXC
039/07; Portarias 267, 359), the Instituto Brasileiro do Meio Ambiente e dos Recursos Naturais Renováveis (IBAMA), and the ICMBio (permits 14789-1, 14789-2). J. S.-C., C. R., and T. R. S. were supported by National Science Foundation (NSF) Grants (DEB-1456964 and DEB-1654829), T. R. S. and J. S.-C. were supported by National Science Foundation (NSF) Grant DEB-0949689, and the National Museum of Natural History (NMNH) Small Grants program; T. R. S. by the Smithsonian Institution Scholarly Studies Program; J. S.-C. and A. J. by NMNH Peter Buck Predoctoral Fellowships and Max and Vera Britton Environmental Science Awards (Cosmos Club Foundation); and M. B. and A. R. by the Fundação de Amparo à Pesquisa do Estado de São Paulo (FAPESP; 2011/50226-0; 2014/24298-1, respectively) and CNPq (311562/2012-4 and 487639/2012-0).

\section{References}

Aylward FO, Burnum-Johnson KE, Tringe SG, Teiling C, Tremmel DM, Moeller JA, Scott JJ, Barry KW, Piehowski PD, Nicora CD, Malfatti SA, Monroe ME, Purvine SO, Goodwin LA, Smith RD, Weinstock GM, Gerardo NM, Suen G, Lipton MS, Currie CR (2013) Leucoagaricus gongylophorus produces diverse enzymes for the degradation of recalcitrant plant polymers in leaf-cutter ant fungus gardens. Appl Environ Microb 79:3770-3778. doi:10.1128/AEM.03833-12 
Cordani UG, Teixeira W, D’Agrella-Filho MS, Trindade RI (2009) The position of the Amazonian Craton in supercontinents. Gondwana Res 15:396-407. doi:10.1016/j.gr.2008.12.005

De Fine Licht HH, Boomsma JJ, Tunlid A (2014) Symbiotic adaptations in the fungal cultivar of leaf-cutting ants. Nat Commun 5:5675-5675. doi:10.1038/ncomms6675

De Fine Licht HH, Schiøtt MM, Rogowska-Wrzesinska A, Nygaard SS, Roepstorff PP, Boomsma JJ (2013) Laccase detoxification mediates the nutritional alliance between leaf-cutting ants and fungus-garden symbionts. Proc Natl Acad Sci USA 110:583587. doi:10.1073/pnas.1212709110

Gauld I, Bolton B (1988) The Hymenoptera. Oxford University Press in association with British Museum (Natural History)

Gumier-Costa F, Sperber CF (2009) Atropelamentos de vertebrados na Floresta Nacional de Carajás, Pará, Brasil. Acta Amaz 39:1-10

Jesovnik A, González VL, Schultz TR (2016) Phylogenomics and divergence dating of fungus-farming ants (Hymenoptera: Formicidae) of the genera Sericomyrmex and Apterostigma. PLoS ONE 11:e0151059. doi:10.1371/journal.pone.0151059

Jesovnik A, Sosa-Calvo J, Lopes CT, Vasconcelos HL, Schultz TR (2013) Nest architecture, fungus gardens, queen, males, and larvae of the fungus-growing ant Mycetagroicus inflatus Brandão \& Mayhé-Nunes. Insect Soc 60:531-542. doi:10.1007/ s00040-013-0320-8

Klingenberg C, Brandão CRF (2009) Revision of the fungus-growing ant genera Mycetophylax Emery and Paramycetophylax Kusnezov rev. stat., and description of Kalathomyrmex n. gen. (Formicidae: Myrmicinae: Attini). Zootaxa 2052:1-31

Kooij PW, Aanen DK, Schiøtt M, Boomsma JJ (2015) Evolutionarily advanced ant farmers rear polyploid fungal crops. J Evol Biol 28:1911-1924. doi:10.1111/jeb.12718

Lattke JE (1999) A new species of fungus-growing ant and its implications for attine phylogeny (Hymenoptera: Formicidae). Syst Entomol 24:1-6

Lopes JFS, Hughes WOH, Camargo RS, Forti LC (2005) Larval isolation and brood care in Acromyrmex leaf-cutting ants. Insect Soc 52:333-338. doi:10.1007/s00040-005-0816-y

Masiulionis VE, Rabeling C, De Fine Licht HH, Schultz T, Bacci M, Bezerra CMS, Pagnocca FC (2014) A Brazilian population of the asexual fungus-growing ant Mycocepurus smithii (Formicidae, Myrmicinae, Attini) cultivates fungal symbionts with gongylidia-like structures. PLoS ONE 9:e103800. doi:10.1371/ journal.pone. 0103800

Mehdiabadi NJ, Mueller UG, Brady SG, Himler AG, Schultz TR (2012) Symbiont fidelity and the origin of species in fungus-growing ants. Nat Commun 3:840-840. doi:10.1038/ ncomms 1844

Mikheyev AS, Mueller UG, Abbot P (2010) Comparative dating of attine ant and lepiotaceous cultivar phylogenies reveals coevolutionary synchrony and discord. Am Nat 175:E126-E133. doi:10.1086/652472

Mikheyev AS, Mueller UG, Boomsma JJ (2007) Population genetic signatures of diffuse co-evolution between leafcutting ants and their cultivar fungi. Mol Ecol 16:209-216. doi:10.1111/j.1365-294X.2006.03134.x

Mikheyev AS, Vo T, Mueller UG (2008) Phylogeography of postPleistocene population expansion in a fungus-gardening ant and its microbial mutualists. Mol Ecol 17:4480-4488. doi:10.1111/j.1365-294X.2008.03940.x

Mueller UG, Rehner SA, Schultz TR (1998) The evolution of agriculture in ants. Science 281:2034-2038. doi:10.1126/ science.281.5385.2034

Mueller UG, Schultz TR, Currie C, Adams RMM, Malloch D (2001) The origin of the attine ant-fungus mutualism. Q Rev Biol 76:169-197
Nygaard S, Hu H, Li C, Schiøtt M, Chen Z, Yang Z, Xie Q, Ma C, Deng Y, Dikow RB, Rabeling C, Nash DR, Wcislo WT, Brady SG, Schultz TR, Zhang G, Boomsma JJ (2016) Reciprocal genomic evolution in the ant-fungus agricultural symbiosis. Nat Commun 7:12233. doi:10.1038/ncomms 12233

Nygaard S, Zhang G, Schiøtt M, Li C, Wurm Y, Hu H, Zhou J, Ji L, Qiu F, Rasmussen M (2011) The genome of the leaf-cutting ant Acromyrmex echinatior suggests key adaptations to advanced social life and fungus farming. Genome Res 21:1339-1348. doi:10.1101/gr.121392.111

Rabeling C, Bacci M (2010) A new workerless inquiline in the Lower Attini (Hymenoptera: Formicidae), with a discussion of social parasitism in fungus-growing ants. Syst Entomol 35:379-392. doi:10.1111/j.1365-3113.2010.00533.x

Rabeling C, Cover SP, Johnson RA, Mueller UG (2007a) A review of the North American species of the fungus-gardening ant genus Trachymyrmex (Hymenoptera: Formicidae). Zootaxa 1664:1-53

Rabeling C, Gonzales O, Schultz TR, Bacci M Jr, Garcia MVB, Verhaagh M, Ishak HD, Mueller UG (2011) Cryptic sexual populations account for genetic diversity and ecological success in a widely distributed, asexual fungus-growing ant. Proc Natl Acad Sci USA 108:12366-12371. doi:10.1073/pnas.1105467108

Rabeling C, Schultz TR, Bacci M Jr, Bollazzi M (2015) Acromyrmex charruanus: a new inquiline social parasite species of leaf-cutting ants. Insect Soc 62:335-349. doi:10.1007/ s00040-015-0406-6

Rabeling C, Verhaagh M, Engels W (2007b) Comparative study of nest architecture and colony structure of the fungus-growing ants, Mycocepurus goeldii and M. smithii. J Insect Sci 7:1-13. doi:10.1673/031.007.4001

Schneider M, Bueno OC, Hebling MJA, Pagnocca FC (2000) Observations on brood care behaviour of the leafcutting ant Atta sexdens L. (Hymenoptera: Formicidae). In: XXI international congress of entomology, pp 20-26

Schultz TR, Meier R (1995) A phylogenetic analysis of the fungusgrowing ants (Hymenoptera: Formicidae: Attini) based on morphological characters of the larvae. Syst Entomol 20:337-370. doi:10.1111/j.1365-3113.1995.tb00100.x

Schultz TR (1993) Stalking the wild attine. Notes Undergr 8:7-10

Schultz TR (2007) The fungus-growing ant genus Apterostigma in Dominican amber. Mem Am Entomol Soc 80:425-436

Schultz TR, Brady SG (2008) Major evolutionary transitions in ant agriculture. Proc Natl Acad Sci USA 105:5435-5440. doi:10.1073/pnas.0711024105

Schultz TR, Sosa-Calvo J, Brady SG, Lopes CT, Mueller UG, Bacci M Jr, Vasconcelos HL (2015) The most relictual fungus-farming ant species cultivates the most recently evolved and highly domesticated fungal symbiont species. Am Nat 185:693-703. doi:10.1086/680501

Seal JN, Gus J, Mueller UG (2012) Fungus-gardening ants prefer native fungal species: do ants control their crops? Behav Ecol 23:1250-1256. doi:10.1093/beheco/ars109

Seal JN, Mueller UG (2014) Instability of novel ant-fungal associations constrains horizontal exchange of fungal symbionts. Evol Ecol 28:157-176. doi:10.1007/s10682-013-9665

Serna F, Mackay W (2010) A descriptive morphology of the ant genus Procryptocerus (Hymenoptera: Formicidae). J Insect Sci 10:111. doi:10.1673/031.010.11101

Sosa-Calvo J, Jesovnik A, Okonski E, Schultz TR (2015) Locating, collecting, and maintaining colonies of fungus-farming ants (Hymenoptera: Myrmicinae: Attini). Sociobiology 62:300-320. doi:10.13102/sociobiology.v62i2.300-320

Sosa-Calvo J, Schultz TR (2010) Three remarkable new fungus-growing ant species of the genus Myrmicocrypta (Hymenoptera: Formicidae), with a reassessment of the characters that define the 
genus and its position within the Attini. Ann Entomol Soc Am 103:181-195. doi:10.1603/AN09108

Sosa-Calvo J, Schultz TR, Brandão CRF, Klingenberg C, Feitosa RM, Rabeling C, Bacci M Jr, Lopes CT, Vasconcelos HL (2013) Cyatta abscondita: Taxonomy, evolution, and natural history of a new fungus-farming ant genus from Brazil. PLoS ONE 8:e80498. doi:10.1371/journal.pone.0080498

Suen G, Teiling C, Li L, Holt C, Abouheif E, Bornberg-Bauer E, Bouffard P, Caldera EJ, Cash E, Cavanaugh A (2011) The genome sequence of the leaf-cutter ant Atta cephalotes reveals insights into its obligate symbiotic lifestyle. PLoS Genet 7:e1002007. doi:10.1371/journal.pgen.1002007

Teixeira JBG, Misi A, da Glória da Silva M (2007) Supercontinent evolution and the Proterozoic metallogeny of South America. Gondwana Res 11:346-361. doi:10.1016/j.gr.2006.05.009
Trendall AF, Basei MAS, De Laeter JR, Nelson DR (1998) SHRIMP zircon $\mathrm{U}-\mathrm{Pb}$ constraints on the age of the Carajás formation, Grão Pará Group, Amazon Craton. J S Am Earth Sci 11:265277. doi:10.1016/S0895-9811(98)00015-7

Ward PS, Brady SG, Fisher BL, Schultz TR (2015) The evolution of myrmicine ants: phylogeny and biogeography of a hyperdiverse ant clade (Hymenoptera: Formicidae). Syst Entomol 40:61-81. doi:10.1111/syen. 12090

Wheeler GC, Wheeler J (1976) Ant larvae: Review and synthesis. Mem Entomol Soc Wash 7:1-108

Wilson EO (1971) The insect societies. The insect societies. Belknap Press, Cambridge 